\title{
A Systematic Review on the Strategic Utilization of Information Systems and IT Infrastructure Flexibility
}

\author{
Norizan Anwar, Mohamad Noorman Masrek and Mad KhirJohari Abdullah Sani
}

Universiti Teknologi MARA, Shah Alam, Malaysia

Correspondence should be addressed to: Norizan Anwar; norizananwar@gmail.com

Received date: 10 September 2015; Accepted date: 8 August 2016; Published date: 14 March 2017

Academic Editor: Maslin Masrom

Copyright (C) 2017. Norizan Anwar, Mohamad Noorman Masrek and Mad KhirJohari Abdullah Sani.

\begin{abstract}
IT infrastructure is a crucial element in any organization across industry. It does not matter which industry are you in, i.e. manufacturing, education, cosmetic, automobile, health and much more required sufficient IT backbone to support these industries day-to-day operation. To remain relevant in their respective market, they need to be competitive with their competitors. It is recommended that the organization fully utilizes their information systems to forecast and measure their product or services offered. In a way, information systems are able to lead the managers or decision makers to maximize their ability, capability, wisely and strategically use information systems in assisting them to direct, evaluate, guide and suggest for better decision making. Therefore, this study attempts to identify the determinants of strategic utilization of information systems. Literally, most researchers identified determinants of any subject matters through literature review processes. The mechanism in capturing determinants over literature review processes varies to one another among researchers. Mainly in this study, the researchers decided to use systematic review as it is one of the best ways for the researchers to dig and evaluate which of the dimensions best suit both dependent variables (DV) and independent variables (IV). In the process of systematic review, five (5) components were involved, such as problem formulation; literature search; data evaluation; data analysis; and interpretation of results. Respective variable findings were drawn using schematic and it led the researchers to decide which dimension is best to represent respective variable.
\end{abstract}

Keywords: systematic review, IT infrastructure, flexibility, strategic utilization, information systems, phrase, literature review

Distributed under Creative Commons CC-BY 4.0

Cite this Article as: Norizan Anwar, Mohamad Noorman Masrek and Mad KhirJohari Abdullah Sani (2017)," A Systematic Review on the Strategic Utilization of Information Systems and IT Infrastructure Flexibility", Communications of the IBIMA, Vol. 2017 (2017), Article ID 518818, DOI: 10.5171/2017.518818 


\section{Introduction}

The dependency of Information technology (IT) can be seen in various scopes and functions in an organization in order to support their daily business functions. The organization will always ensure that their IT infrastructure is workable at any time. This is to ensure that there will be no transaction distortions and they will be able to achieve high return on investment (ROI), to some extent, some organizations are willing to spend some amount of money in order to ensure that their IT infrastructure is in tip top condition. IT infrastructure is classified into two (2), such technical (Duncan, 1995) and human IT infrastructure (Byrd \& Turner, 2000 \& 2001 \& Chanopas, Krairit \& Khang, 2006). In extend, Byrd \& Turner (2000) and Duncan (1995) mention that technical IT infrastructure shall consist of the hardware and operating systems (platform technology), network technologies, data and application software. Meanwhile, human IT infrastructure is all about human and organizational skills, expertise, competencies, knowledge, commitments, values, norms and organizational structure (Byrd \& Turner, 2000). However, Fink \& Neumann (2009) developed a multidimensional definition of IT infrastructure where with addition of process IT infrastructure. Thus, they had identified a range of physical and managerial capabilities as the dimensions under this concept.

The demands of using IT infrastructure force it to be flexible to their user whenever required. To become flexible, IT infrastructure shall cater for all three (3) concepts mentioned above accordingly. Yearly studies and papers done produced a report on this concept across disciplines. In the beginning studies conducted by Duncan (1995), Chung, Rainer \& Lewis (2003), Fink \& Neumann (2009), Byrd \& Turner (2000 \& 2001), Zhang \& Ziegelmayer (2009), Chung et. al. (2005), Bush, Tiwana \& Rai (2010), Sirkemaa (2002), Bhatt et al. (2010), Masrek
\& Jusoff (2009), Zainon \& Salleh (2011) etc., found four (4) dimensions: compatibility, modularity, connectivity and IT personnel that had been discussed throughout the years. However, studies by Gholami, Kaviani \& Zabihi (2003) and Chanopas, Krairit \& Khang (2006) found additional five dimensions: scalability, continuity, rapidity, facility and modernity.

An organization may use either Electronic systems (e-commerce) or Mobile commerce systems (m-commerce); Transaction Processing Systems (TPS); Management Information Systems (MIS); and Decision Support Systems (DSS) to support their business operation and to achieve their business goals and all these are examples of Information systems (IS). Limited studies have been conducted on strategic use in the context of IS. Masrek, Jamaludin \& Hashim (2009) proposed conceptual framework for studying the effect of technological, organizational and environmental factors on the strategic utilization of information systems. Meanwhile, unpublished thesis by Jamaludin (1996) was investigating factors that influence the strategic utilization of information resources (SUIR). Thus, both studies introduced dimensions such as product differentiation, cost leadership and growth advantage as part of the concept of the strategic use of IS.

Overall, in this systematic review, the researchers intended to find the following objectives:

1. To structuring the overview of strategic utilization of information systems.

2. To structuring the overview of IT infrastructure flexibility.

The rest of this paper is as follows. Section 2 introduces the research methodology. Section 3 provides the systematic review findings. Section 4 ends the paper with a discussion and conclusion. 


\section{Methodology}

At the beginning of getting the idea about the topic, researchers are doing traditional or conventional way of literature review. The process of searching, collecting and reading those literatures in getting glasses or surface idea about the research topic is sufficient at that point of time. To streamline further as which concept, variables and dimensions to choose, systematic review was found to be suitable in this study.

To create maximization and optimization in new and existing literature collections, we adopt the work from (Cooper \& Hedges, 2009) and it is widely used i.e. (Kobus \& Westner, 2015). Table 1 shows the stages of systematic

review.

\section{Table 1: Stages of Systematic Review}

\begin{tabular}{|c|l|}
\hline Stages & \multicolumn{1}{|c|}{ Details } \\
\hline Problem formulation & $\begin{array}{l}\text { Research items are retrieved, examined, and archived using pre- } \\
\text { defined keyword search in electronic databases }\end{array}$ \\
\hline [ & \\
\hline Literature search & $\begin{array}{l}\text { Non-relevant research items are excluded from further analysis } \\
\text { (as the database-driven search approach might return non- } \\
\text { relevant results) }\end{array}$ \\
\hline [ & \\
\hline Data Evaluation & Remaining research items are categorized \\
\hline ? & \\
\hline Data Analysis & Emerging themes of research are determined \\
\hline ? & \\
\hline Interpretation of Results & The validity of research is described \\
\hline
\end{tabular}

\section{Literature Retrieval}

In the process of searching and retrieving, this study focused on peer-reviewed journals and conferences on selected online databases that have been decided earlier. List of searches focus by online databases is shown in Table 2. 
Table 2: Searching Focus by Online Databases

\begin{tabular}{|l|l|}
\hline Search Focus & Searched Online Databases \\
\hline Journals & $\begin{array}{l}\text { ACM Digital Library, ProQuest, Emerald Insight, ScienceDirect, Scopus, } \\
\text { Web Of Science, Wiley Online Library, Google, Google Scholar }\end{array}$ \\
\hline Conferences & IEEE Xplore, Google, Google Scholar \\
\hline
\end{tabular}

Upon deciding which online databases to use, the researchers set several phrases to use during the searching process. The phrase is based on the theme that reflects the concept of this study. For the journals and conference papers or proceeding papers, the searching was derived not using any solid keywords, combination of keywords and string such AND, OR, “', '-', '+' etc. In this case, the researchers prefer more to use phrases that reflect the topic of the study. For the first $\left(1^{\text {st }}\right)$ and second $\left(2^{\text {nd }}\right)$ iteration, the researchers use phrases that related to the independent variable (IV) while the phase that related to the dependent variable (DV) was during the third ( $3^{\text {rd }}$ ) iteration. Thus, the searching was done three (3) iterations with different phases. Below is the list of phrases that researchers used in this study:

Table 3: The List of Phases Used during the Searching

\begin{tabular}{|l|l|}
\hline Iterations & Phase \\
\hline $1^{\text {st }}$ & IT Infrastructure \\
& Technology Infrastructure \\
& System Infrastructure \\
& IS Infrastructure \\
\hline $2^{\text {nd }}$ & $\begin{array}{l}\text { Information Technology Infrastructure Flexibility } \\
\text { IT Infrastructure Flexibility } \\
\end{array}$ \\
& $\begin{array}{l}\text { Information Systems Infrastructure Flexibility } \\
\text { Information Technology Architecture Flexibility } \\
\end{array}$ \\
\hline
\end{tabular}




\begin{tabular}{|c|l|}
\hline Iterations & Phase \\
\hline & $\begin{array}{l}\text { Information Systems Architecture Flexibility } \\
\text { IS Architecture Flexibility }\end{array}$ \\
\hline $3^{\text {rd }}$ & $\begin{array}{l}\text { Strategic Use of Information System } \\
\text { Strategic Use of Information Technology } \\
\text { Competitive Advantage of Information System } \\
\text { Competitive Advantage of Information Technology } \\
\text { Strategic Utilization of Information System } \\
\text { Strategic Utilization of Information Technology }\end{array}$ \\
\hline
\end{tabular}

\section{Literature Exclusion}

In this systematic review searching or query, the researchers do not eliminate the use of abbreviation of certain words such as "IT" for Information Technology and "IS" for Information System and this also had been done by (Kobus \& Westner, 2015).All words and abbreviations are used to give a higher probability of getting any closer journal or conference papers or proceeding papers that most matched the searching.

No matter which online databases are used, the same search strategy was applied across these three (3) iterations. Whenever there were no results, another or broader phrase search was used as shown in Table 3. The extensive use of broader keyword is necessary during the searching. After all, any journal or conference papers or proceeding papers were excluded when the researchers found them not relevant for the study. According to (Kobus \& Westner, 2015), all these journal or conference papers or proceeding papers can be considered not relevant whenever at least one of the following criteria was applied: 
Table 4: Criteria in Filtering the Searching

\begin{tabular}{|c|l|}
\hline Criteria & Explanations \\
\hline 1 & $\begin{array}{l}\text { Its main focus is not on "strategic" in the context of the Utilization of IS and } \\
\text { "flexibility" in organization's IT Infrastructure }\end{array}$ \\
\hline 2 & $\begin{array}{l}\text { Its main focus is not on the Utilization of IS with sub-focus on "strategic" and } \\
\text { "flexibility" in organization's IT Infrastructure }\end{array}$ \\
\hline 3 & Its length is 2 pages or less \\
\hline 4 & $\begin{array}{l}\text { It does not apply any of the Strategic Utilization of Information Systems or IT } \\
\text { Infrastructure Flexibility point of view }\end{array}$ \\
\hline 5 & $\begin{array}{l}\text { It has no original content (e.g. syllabus of study in any program offer, proposals } \\
\text { describing only planned research, foreword in any conferences or seminars) or } \\
\text { resulted in a journal }\end{array}$ \\
\hline
\end{tabular}

\section{Literature Categorization}

After applying the above criteria as in Table 4 , leaving 472 journals or conference papers or proceeding papers to proceed with the literature categorization. All relevant and matched journal or conference papers or proceeding papers were kept and managed accordingly. Each group of phase that had been set earlier was used at each online database. Upon filtering and exclusion, each literature was managed and labelled respectively by dedicated folder as illustrated in figure 2 below:

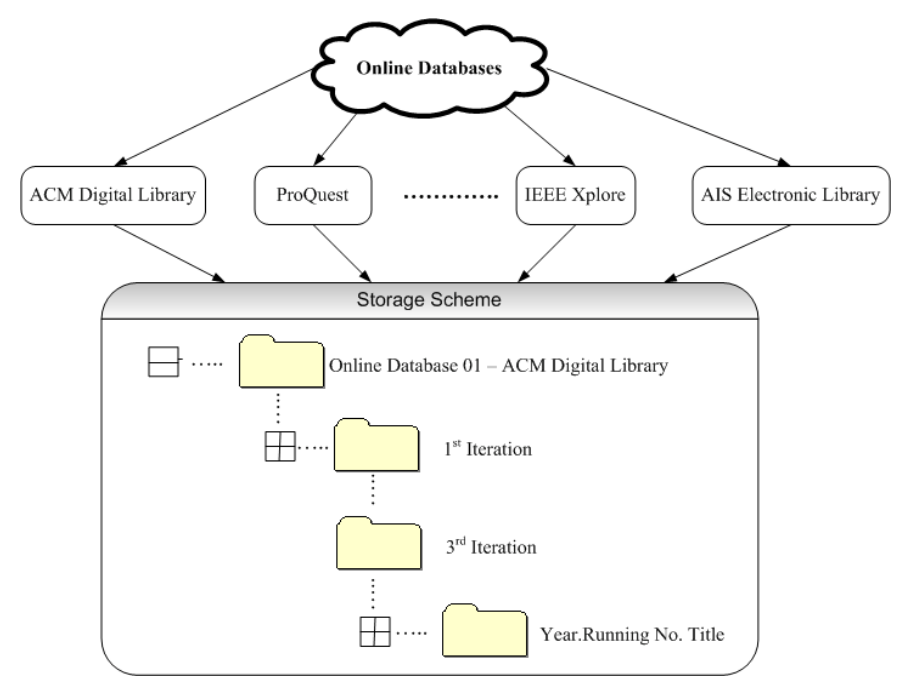

Figure 1: Literature Management 
The next phase is extracting the key point at each literature. The main purposes are to identify the dimensions of strategic utilization of information systems and the dimensions of IT infrastructure flexibility. In order to capture and identify those dimensions, the researchers follow (Dibbern, Goles, Hirschheim and Jayatilaka, 2004) as also adopted by (Kobus \& Westner, 2015) and little enhancement has been made. Originally, the categorization of items is reference theory; research approach; research type; data gathering and data analysis. Field of the literature and country has been add-up with this note taking.

\section{Results \\ Descriptive Analysis: Selection of Relevant Literature}

The search resulted in a total of 472 journals or conference papers or proceeding papers that were extracted for three consecutive months and the breakdown by iteration is shown in Table 5. All this literature is initially in scope for literature review. On top of that, all these literatures were examined and analyzed their relevancy in order to identify the dimensions of strategic utilization of information systems and the dimensions of IT infrastructure flexibility.

Table 5: The Breakdown by Iteration

\begin{tabular}{|c|c|c|c|c|c|c|c|c|c|c|}
\hline \multirow[b]{2}{*}{ Searching Area } & \multicolumn{10}{|c|}{ Online Database } \\
\hline & 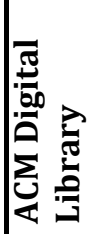 & $\begin{array}{l}\vec{y} \\
\stackrel{0}{z} \\
0 \\
\dot{0}\end{array}$ & 苞 & 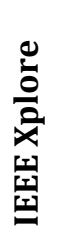 & 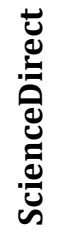 & 苛 & 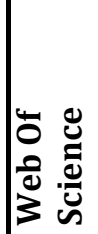 & 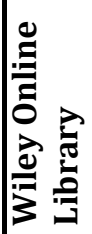 & $\begin{array}{l}\stackrel{0}{0} \\
\dot{0} 0 \\
0 \\
0\end{array}$ & 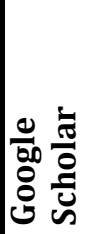 \\
\hline $1^{\text {st }}$ Iteration & 6 & 6 & 12 & 4 & 7 & 2 & 0 & 2 & 14 & 13 \\
\hline $2^{\text {nd }}$ Iteration & 13 & 35 & 17 & 21 & 36 & 4 & 6 & 6 & 27 & 43 \\
\hline $3^{\text {rd }}$ Iteration & 17 & 5 & 63 & 25 & 55 & 3 & 3 & $*$ & 16 & 11 \\
\hline
\end{tabular}

* Pdf file cannot open

\section{The Dimensions of Variables}

Using the literature categorization by (Dibbern, Goles, Hirschheim and Jayatilaka, 2004), researchers were able to identify every dimension respectively. As mentioned above, the first $\left(1^{\text {st }}\right)$ and second $\left(2^{\text {nd }}\right)$ iteration were searching the independent variable (IV) while the dependent variable (DV) was during the third (3rd) iteration. At first, researchers used the generic template or form to fill-up information according to the literature categorization. Based on this form, researchers transforms into a table and diagram (was inspired and shared by one of the friends in the Facebook Doctorate Support Group) which appropriate to get a clearer picture on the selection of the dimensions. The summary of the DV is shown in Figure 4 and the IV is shown in Table 6 respectively. The results show only some part or most prominent authors and not from 
all literatures. With the use of systematic review exercise, it helps researchers a lot in framing and confirming which dimensions to use for the study.

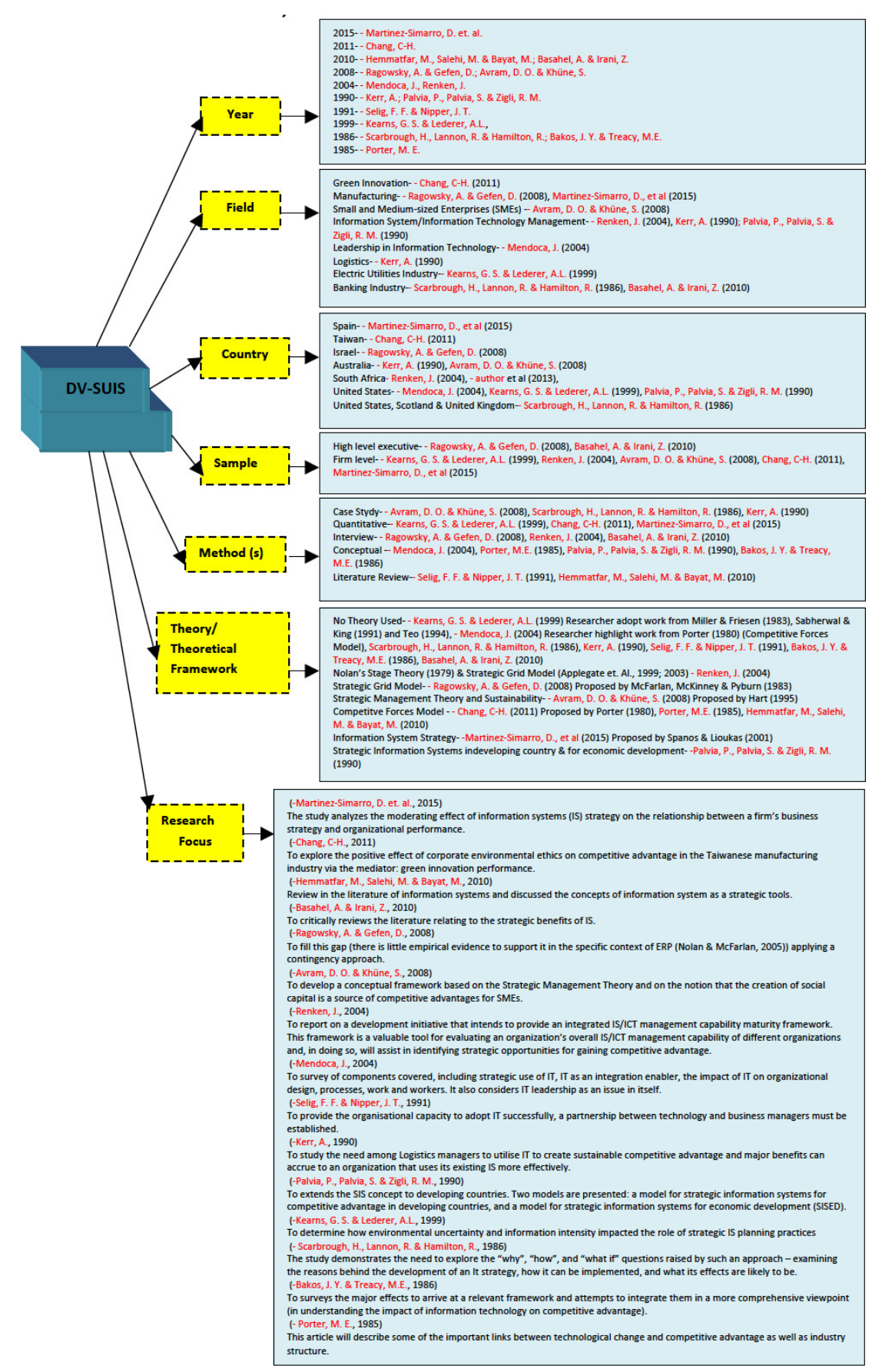

Figure 2: The Summary of Dimension for the Dependent Variable (DV)

Norizan Anwar, Mohamad Noorman Masrek and Mad KhirJohari Abdullah Sani (2017), Communications of the IBIMA, DOI: $10.5171 / 2017.518818$ 
Table 6: The Summary of Dimension for the Independent Variable (IV)

\begin{tabular}{|c|c|c|c|c|c|c|c|c|c|c|}
\hline \multirow[b]{2}{*}{ Author(s) } & \multicolumn{4}{|c|}{ Human IT Infrastructure } & \multicolumn{4}{|c|}{$\begin{array}{l}\text { Technical IT } \\
\text { Infrastructure }\end{array}$} & \multicolumn{2}{|c|}{$\begin{array}{c}\text { Process IT } \\
\text { Infrastructure }\end{array}$} \\
\hline & 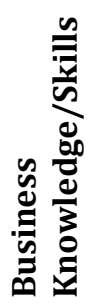 & 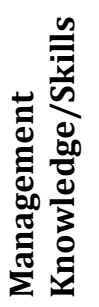 & 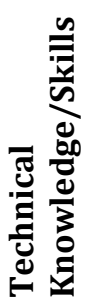 & 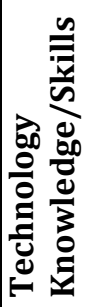 & 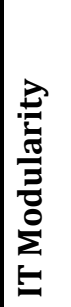 & 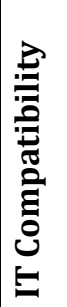 & 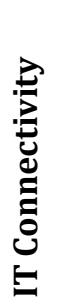 & 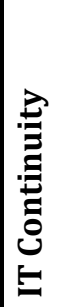 & 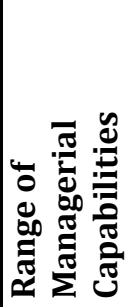 & 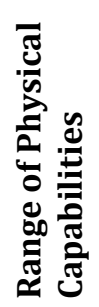 \\
\hline $\begin{array}{l}\text { Byrd \& Turner, } \\
2000\end{array}$ & $\checkmark$ & $\checkmark$ & $\sqrt{ }$ & $\checkmark$ & & $\checkmark$ & $\checkmark$ & & & \\
\hline $\begin{array}{l}\text { Byrd \& Turner, } \\
2001\end{array}$ & $\sqrt{ } \cdot$ & & $\checkmark$ & $\checkmark$ & & $\checkmark$ & $\checkmark$ & & & \\
\hline Sirkemaa, 2002 & & & & & & & $\checkmark$ & & & \\
\hline Chen, 2003 & $\checkmark$ & & $\checkmark$ & & & & & & & \\
\hline $\begin{array}{l}\text { Chung, Rainer \& } \\
\text { Lewis, } 2003\end{array}$ & & & & & $\checkmark$ & $\checkmark$ & $\checkmark$ & & & \\
\hline Chung et. al., 2005 & & & $\sqrt{ }$ & $\checkmark$ & $\checkmark$ & $\checkmark$ & $\checkmark$ & & & \\
\hline $\begin{array}{l}\text { Chanopas, Krairit } \\
\text { \& Khang, } 2006\end{array}$ & & & $\checkmark$ & $\checkmark$ & $\checkmark$ & $\checkmark$ & $\checkmark$ & $\checkmark$ & & \\
\hline $\begin{array}{l}\text { Fink \& Neumann, } \\
2009\end{array}$ & $\checkmark$ & $\checkmark$ & $\checkmark$ & $\checkmark$ & $\checkmark$ & $\checkmark$ & $\checkmark$ & $\checkmark$ & $\checkmark$ & $\checkmark$ \\
\hline $\begin{array}{l}\text { Gholami, Kaviani \& } \\
\text { Zabihi, } 2009\end{array}$ & & & $\checkmark$ & $\checkmark$ & $\checkmark$ & $\checkmark$ & $\checkmark$ & $\checkmark$ & & \\
\hline $\begin{array}{l}\text { Zhang, Li \& } \\
\text { Ziegelmayer, } 2009\end{array}$ & & & $\checkmark$ & $\checkmark$ & $\checkmark$ & $\checkmark$ & $\checkmark$ & & & \\
\hline $\begin{array}{l}\text { G. Bhatt et al., } \\
2010\end{array}$ & & & & & $\checkmark$ & $\checkmark$ & & & & \\
\hline $\begin{array}{l}\text { Bush, Tiwana \& } \\
\text { Rai, } 2010\end{array}$ & & & & & $\checkmark$ & $\checkmark$ & $\checkmark$ & & & \\
\hline
\end{tabular}




\section{Discussion \& Conclusion}

The selection of the dimensions for the DV and IV was basically derived from the results of the systematic review conducted. By doing the systematic review, researchers get clearer picture on the evolution of each variable; which field has adapted and adopted the concept; what type of methodology that other researchers did etc. To understand the whole concepts of the study, researchers need 360 degree view about it. The motivation of the study was captured too through this systematic review.

The hassle in doing systematic review is where the researchers required capturing every single process involved. Moreover, the researchers also shall be able to identify important components or section in articles they read and note it down. This is due to some articles that discussed the dimension in narrative methods while others prefer in schematic way. Currency and relevancy are a part of criteria to look into while choosing those dimensions for the DV and IV at the end. Perhaps, this approach also shall be able to search and identify the reasons behind all "how" and "why" in the study.
The approach or method used here best suits any who will like to undergo quantitative study. It is important to identify first the IV and DV involved between concept where no matter what researchers will like to find out in their study which either to measure the difference, correlation or factors that influence between concept.

Based on the systematic review conducted, the choice of these dependent variables to form the framework is taken from the previous works by (Masrek, Jamaludin \& Hashim, 2009; Jamaludin, 1996), which are product/service differentiation; cost leadership and growth advantage. While for the independent variable, this study will measure the dimensions of IT infrastructure flexibility, such as Human, Technical and Process IT infrastructure (Masrek, Jamaludin \& Hashim, 2009; Jamaludin, 1996; Hilhorst, Ribbers, Heck \& Smits, 2008; Duncan, 1995; Chung, Rainer \& Lewis, 2003; Fink \& Neumann, 2009; Byrd \& Turner, 2000; Byrd \& Turner, 2001; Zhang, Li \& Ziegelmayer, 2009; Chung et al., 2005; Bush, Tiwana \& Rai, 2010; Sirkemaa, 2002; Bhatt et al., 2010; Masrek \& Jusoff, 2009; Zainon \& Salleh, 2011; Gholami, Kaviani \& Zabihi, 2009; Chanopas, Krairit \& Khang, 2006) etc.

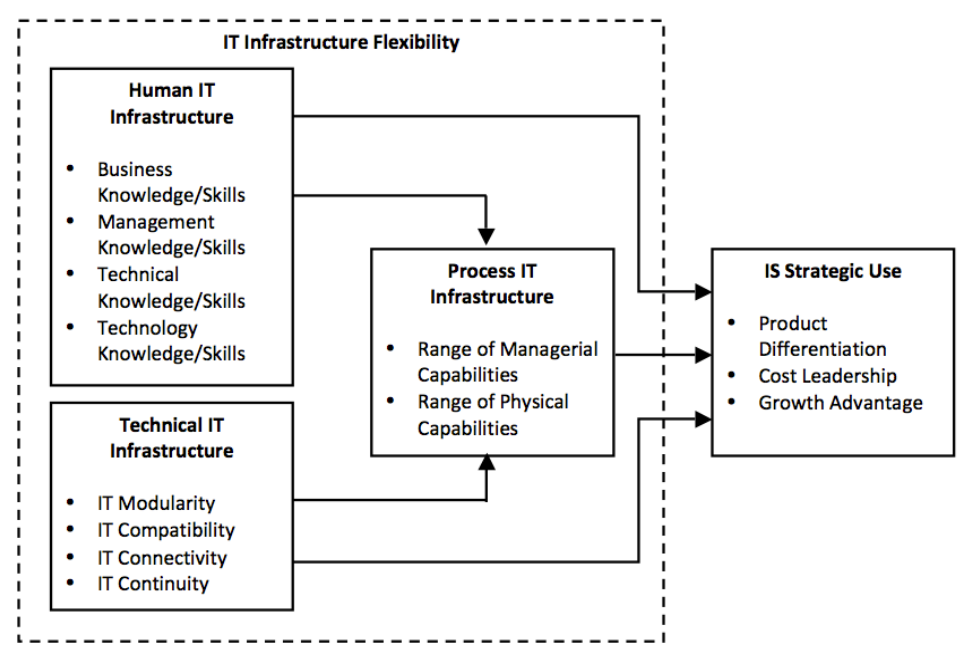

Figure 3: Conceptual Framework 


\section{Acknowledgment}

This research was supported in part by the Ministry of Higher Education (MOHE) and the Research Management Institute (RMI), Universiti Teknologi MARA (UiTM) for funding the research project [ref. no. 600RMI/RAGS 5/3 (142/2012)] and Hazirah Abdul Karim from Facebook Doctorate Support Group for sharing the problem statement and/or literature review in diagram.

\section{References}

1. Avram, D. O. \& Kühne, S. (2008). "Implementing responsible business behavior from a strategic management perspective: Developing a framework for Austrian SMEs", Journal of Business Ethics, $82,463-475$.

2. Bush, A. A., Tiwana, A. \& Rai, A. (2010).“Complementarities Between Product Design Modularity and IT Infrastructure Flexibility in IT-Enabled Supply Chains," IEEE Transactions on Engineering Management, $57(2), 240-254$.

3. Bhatt, G. et al. (2010). "Building and leveraging information in dynamic environments: The role of IT infrastructure flexibility as enabler of organizational responsiveness and competitive advantage," Information \& Management, 47, 341-349.

4. Byrd, T. A. \& Turner, D. E. (2000). "Measuring the Flexibility of Information Technology Infrastructure: Exploratory Analysis of a Construct", Journal of Management Information Systems, 17(1), 167-208.

5. Byrd, T. A. \& Turner, D. E. (2001). "An Exploratory Analysis of the Information Technology Infrastructure Flexibility Construct", Information \& Management, 39, 41-52.
6. Chanopas, A., Krairit, D. \& Khang, D. B. (2006). "Managing information technology infrastructure: a new flexibility framework", Management Research News, 29(10), 632651.

7. Chung, S. H., Rainer, R. K. Jr. \& Lewis, B. R. (2003). "The impact of information technology infrastructure flexibility on strategic alignment and applications implementation," Communications of the Association for Information Systems, 11, 191-206.

8. Chung, S. H. et al. (2005)."An empirical study of the relationships between IT infrastructure flexibility, mass communication and business performance," The database for advances in Information Systems, 36(3), 26-44.

9. Cooper, H. \& Hedges, L.V. (2009). "Research synthesis as a scientific process", The Handbook of Research Synthesis and Meta-Analysis, 2, 3 - 17.

10. Daniels, S. (1998). "The strategic use of information systems", Work Study, 47 (5), $167-171$.

11. Dibbern, J., Goles,T., Hirschheim, R. and Jayatilaka, B. (2004). "Information sytems outsourcing", ACM SIGMIS Database, 35 (4), 6 $-10$.

12. Duncan, N.B. (1995). "Capturing flexibility of information technology infrastructure: a study of resource characteristics and their measure", Journal of Management Information Systems, 12(2), 3757,1995 .

13. Dreyer, B. \& Grønhaug, K. (2004). "Uncertainty, flexibility, and sustained competitive advantage", Journal of Business Research 57, 484-494.

14. Fink, L. \& Neumann, S. (2009). “Exploring the perceived business value of the flexibility enabled by information technology 
infrastructure", Information \& Management, 46, 90-99.

15. Gebauer, J. \& Schober, F. (2006). "Information system flexibility and the cost efficiency of business processes", Journal of the Association for Information Systems, 7 (3), 122-147

16. Gholami, B. Kaviani, F. \& Zabihi, E. (2009). "Web 2.0, a boost in it infrastructure flexibility and team collaboration," 2009 Second International Conference on Computer and Electrical Engineering, 153157.

17. Henderson, J. C. \& Venkatraman, N. (1999). "Strategic alignment- Leveraging IT for transforming organizations", IBM Systems Journal, 32 (1), 472 - 484.

18. Hilhorst, C., Ribbers, P., Heck, E. V. \& Smits, M. (2008).“Using Dempster-Shafer theory and real options theory to assess competing strategies for implementing IT infrastructures: A case study", Decision Support Systems, 46, 344-355

19. Jamaludin, A. (1996). "Penggunaan strategik sumber maklumat (PSSM)", Unpublished thesis. Universiti Sains Malaysia (USM).

20. Kehoe, D., Little, D. \& Lyons, A. (1993)."Strategic planning for information systems enhancement", Integrated Manufacturing Systems, 4(2), 29-36.

21. Kerr, A. (1990). "Information technology: Creating strategic opportunities for logistics", Logistics Information Management, 3(3), 1820.

22. Kobus, J. \& Westner, M. (2015). "Lean management of IT organization: A literature review",PACIS 2015 Proceedings. Retrieved at

http://pacis2015.comp.nus.edu.sg/_proceedi ngs/PACIS_2015_submission_242.pdfon 20 July 2015.
23. Leek, C. (1997)."Information systems frameworks and strategy", Industrial Management \& Data Systems, 97 (3), 86 - 89.

24. Leeuw, A. D. \& Volberda, HW. (1996). "On the concept of flexibility: A dual control perspective", Omega, International Journal Management Science, 24 (2), 121 - 139.

25. Masrek, M. N., Jamaludin, A. \& Hashim, D. M. (2009).“Determinants of strategic utilization of information systems: A conceptual framework," Journal of Software, 4(6), 591-598.

26. Masrek, M. N. \& Jusoff, K. (2009). “The effect of information technology infrastructure flexibility on intranet effectiveness," Computer and InformationScience, 2 (2), 57-67.

27. O'Shaughnessy, N. J. (1996). "Michael Porter's competitive advantage revisited", Management Decision, 34 (6), 12 - 20.

28. Porter, M. E. (1985).“Technology and competitive advantage", Journal of Business Strategy, 5(3), 60-78.

29. Renken, J. (2004). "Developing an IS/ICT management capability maturity framework". Proceedings of SAICSIT 2004, 53-62.

30. Scarbrough, H., Lannon, R., \& Hamilton, R. (1986). "Strategy for information technology: One step beyond", Industrial Management \& Data Systems, 86(1/2), 2-4.

31. Selig, F. F. \& Nipper, J. T. (1991). "Strategic impact of information technology", Industrial Management \& Data Systems, 91(6), $3-4$

32. Sirkemaa, S. (2002). "IT infrastructure management and standards," Proceedings of the International Conference on Information Technology: Coding and Computing (ITCC'02).

33. Zainon, N. \& Salleh, H. (2011). "Dimensions of information technology 
infrastructure flexibility in improving management efficacy of construction industry perspective: A conceptual study," African Journal of Business Management, 5 (17), 7248-7257.
34. Zhang, J., Li, H. \& Ziegelmayer, J. (2009). "Resource or capability? A dissection of SMEs' IT infrastructure flexibility and its relationship with it responsiveness," Journal of Computer Information Systems, 46-53. 